\title{
Penanganan Anak yang Berhadapan Dengan Hukum Kepada Anggota Polisi di Kepolisian Resort (POLRES) Kabupaten Tanjung Jabung Barat
}

\author{
Sri Rahayu, Herry Liyus, Lilik Purwastuti, Dheny Wahyudhi, Dessy Rahkmawty \\ Fakultas Hukum, Universitas Jambi
}

\begin{abstract}
Abstrak: Kegiatan pengabdian pada masyarakat ini dilatarbelakangi adanya permasalahan mitra berkaitan dengan penanganan anak yang berhadapan dengan hukum kepada anggota Polisi di Kepolisian Resort (POLRES) Kabupaten TanjungJabung Barat. Dari pengamatan di lapangan dan berdasarkan data yang di peroleh menunjukkan bahwa masih minimnya pemahaman mitra dalam memahami tentang penanganan anak yang berhadapan dengan hukum, yang diatur dalam Undang-Undang Nomor 23 Tahun 2002 sebagaimana telah diubah melalui Undang-Undang Nomor 35 Tahun 2014 tentang Perlindungan Anak. Untuk mengantisipasi adanya pelanggaran terhadap penanganan anak yang berhadapan dengan hukum, kegiatan ini diusulkan dengan harapan agar ada pemahaman dan penyadaran akan pentingnya perlindungan terhadap anak yang berhadapan dengan hukum. Kegiatan pengabdian ini dilakukan dengan cara sosialisasi dan pelatihan terhadap mitradalam hal ini anggota Polisi di Kepolisian Resort (POLRES)Kabupaten TanjungJabung Barat sebagai khalayak sasaran. Agar lebih memahami undang-undang tentang perlindungan anak. Tujuan dilakukan kegiatan pengabdian ini diharapkan dapat meningkatkan peran aktif, berpartisaipasi, dan peduli terhadap hak anak. Untuk menjawab permasalahan mitra, solusi yang ditawarkan adalah dilakukan pelatihan berupa penyampaian informasi dari narasumber, tanya jawab dan diskusi, berkaitan dengan pemahaman masyarakat tentang penanganan anak yang berhadapan dengan hukum. Aspek yang perlu dipertimbangkan dalam kegiatan ini adalah kelayakan perguruan tinggi, tim pelaksana/instruktur, materi kegiatan dan sarana prasarana. Target luaran yang dihasilkan bertambahnya ilmu pengetahuan dan pemahaman penyidik Polri dalam kaitannya dengan penanganan anak yang bermasalah dengan hukum.
\end{abstract}

\section{PENDAHULUAN}

Suatu aturan dibuat dan disepakati oleh masyarakat adalah sebagai wadah atau sarana untuk mengatur kehidupan masyarakat dan juga sebagai alat kontrol sosial dengan harapan akan tercapainya suatu masyarakat yang teratur, tertib dan aman. Berbagai permasalahan yang sering terjadi di lingkungan sosial masyarakat menyebabkan hukum itu selalu saja menarik untuk dikaji baik secara strukturnya, substansinya maupun dari segi budaya hukum itu sendiri.

Adanya sebuah aturan yang mengatur tatanan hidup bermasyarakat merupakan salah satu cara dari negara dalam mengatur warganegaranya. Salah satu aturan yang mengandung sanksi yang tegas bagi mereka yang melanggar dan membahayakan masyarakat adalah sanksi pidana yang merupakan bagian dari keseluruhan hukum nasional yang mengatur perbuatan yang melanggar hukum, dalam kehidupan bermasyarakat tersebut, tentu membutuhkan pranata hukum yang kuat, dinamis dan yang benar-benar dapat memberikan keadilan bagi masyarakatnya.

Salah satunya adalah pengaturan mengenai perlindungan terhadap anak yang berhadapan dengan hukum, mengingat anak merupakan amanah dan anugerah dari Tuhan yang maha esa yang dalam dirinya melekat harkat dan martabat sebagai manusia seutuhnya. Setiap anak mempunyai harkat dan martabat yang patut dijunjung tinggi dan setiap anak yang terlahir harus mendapatkan hak-haknya tanpa anak tersebut meminta. Hal ini sesuai dengan ketentuan konvensi hak anak yang diratifikasi oleh pemerintah indonesia melalui keputusan Presiden Nomor 36 tahun 1990 yang mengemukakan tentang prinsip-prinsip umum perlindungan anak, yaitu non diskriminasi, kepentingan terbaik anak, kelangsungan hidup dan tumbuh kembang, dan menghargai partisipasi anak. ${ }^{1}$

${ }^{1}$ Rika Saraswaty, Hukum Perlindungan Anak Di Indonesia,Bandung, Citra Aditya Bakti, 2009, hal.1 
Situasi anak di Indonesia saat ini belum dapat dikatakan sejahtera dan belum dapat dikatakan telah terpenuhi hak-haknya.Menurut Barda Nawawi,sebetulnya usaha pembaharuan hukum di Indonesia sudah di mulai sejak lahirnya UUD 1945. Hal ini tidak bisa dilepaskan dari landasan dan sekaligus tujuan yang ingin di capai seperti yang telah di rumuskan dalam pembukaan UUD 1945 yakni melindungi segenap bangsa Indonesia dan untuk memajukan kesejahteraan umum berdasarkan Pancasila. Inilah garis kebijakan umum yang menjadi landasan sekaligus tujuan politik hukum Indonesia. Hal tersebut pula yang mendasari dan menjadi tujuan dari pembaharuan hukum, termasuk pembaharuan di bidang hukum pidana dan penanggulangan kejahatan. ${ }^{2}$

Beberapa peraturan perundang-undangan yang mengatur tentang hak-hak anak dan perlindungan anak yaitu: (1) Undang-Undang No. 4 Tahun 1979 Tentang Kesejahteraan Anak, (2) Kepres Nomor 36 Tahun 1990 Tentang Pengesahan Convention of The Rights/Konvensi Tentang Hak-hak Anak, (3) Undang-undang Tentang HAM, (4) Undang-Undang Nomor 23 Tahun 2002 Tentang Perlindungan Anak, (5) Undang-Undang Nomor 11 Tahun 2012 Tentang Sistem Peradilan Pidana Anak.

Dalam Undang-undang Kesejahteran Anak, menyebutkan bahwa seorang anak berhak atas kesejahteraan, perawatan asuhan berdasarkan kasih sayang, pelayanan untuk berkembang, pemeliharaan dan perlindungan baik semasa dalam kandungan atau setelah dilahirkan. Selanjutnya perlindungan anak berasaskan Pancasila dan UUD 1945 serta prinsip-prinsip Konvensi Hak-hak Anak yang meliputi: (1) Non diskriminasi, (2) Kepentingan yang terbaik bagi anak, (3) Hak untuk hidup, kelangsungan hidup dan perkembangan, dan (4) Penghargaan terhadap pendapat anak.

Perlidungan hukum terhadap anak merupakan kewajiban bagi kita semua mengingat anak sebagai generasi penerus bangsa yang memiliki peranan strategis dalam mewujudkan citacita bangsa, oleh sebab itu anak harus mendapatkan pembinanaan dan perlindungan sehingga mereka dapat tumbuh dan berkembang dengan baik. Anak termasuk kelompok yang rentan terhadap terjadinya suatu tindak pidana baik sebagai korban, saksi, maupun sebagai pelaku dari suatu tindak pidana.

Dalam pengamatan ternyata keberadaan peraturan perundang-undangan yang menjamin perlindungan anak masih belum diterapkan secara maksimal. Kekerasan terhadap anak masih saja terjadi. Salah satu indikator penyebabnya adalah tingkat pemahaman tentang penanganan anak yang berhadapan dengan hukum baik oleh penegak hukum maupun masyarakat yang masih kurang. Atau tidak dapat berfungsinya hukum dengan baik bisa jadi disebabkan oleh belum sampainya berbagai peraturan yang menjamin perlindungan anak sampai pada tingkat masyarakat. Oleh karena itu diperlukan penyebar luasan pemahaman berbagai peraturan berkaitan dengan perlindungan anak. Untuk itu maka perlu dilakukan sosialisasi peraturan perundangan terhadap masyarakat luas. Sasaran strategis yang dianggap efektif dalam penyadaran tentang penanganan anak yang berhadapan dengan hukum adalah kalangan anggota polisi. Sasaran strategis tersebut sangat relevan, karena secara langsung mereka terlibat dalam penanganan anak yang berhadapan dengan hukum.

\section{PERMASALAHAN MITRA}

${ }^{2}$ Barda Nawawi Arif, Bunga Rampai Kebijakan Hukum Pidana Perkembangan Penyusunan KUHP Baru,Jakarta, Kencana, 2008, hal. 34. 
Dari uraian diatas maka permasalahan yang menjadi fokus perhatian dalam pengabdian pada masyarakat ini adalah "Penanganan Anak Yang Berhadapan Dengan HukumKepadaAnggota Polisi Di Kepolisian Resort (POLRES)Kabupaten TanjungJabung Barat".Selain orang tua dan tokoh masyarakat. Pemuda juga relevan sebagai khalayak sasaran yang strategis dalam kegiatan pemahaman masyarakat tentang anak yang berhadapan dengan hukum, sebagai alasan perlunya menyamakan persepsi oleh semua pihak termasuk penyelesaian terhadap anak yang berhadapan dengan hukum. Untuk mewujudkan partisipasi masyarakat dalam meningkatkan taraf kehidupannya, hidup tentram, aman, damai, bahagia, sejahtera lahir dan batin serta memperoleh lingkungan hidup yang baik dan sehat.

Kekerasan terhadap anak dapat terjadi dimana saja. Beberapa jenis kekerasan dapat dikelompokkan kedalam kekerasan fisik, kekerasan psikis/mental, kekerasan seksual, maupun kekerasan ekonomi.Selama ini memang masih ada perbedaan persepsi tentang penanganan anak yang berhadapan dengan hukum. Untuk mewujudkan lingkungan yang ramah anak dan terhindar dari kekerasan, maka harus ada persamaan persepsi tentang kekerasan oleh semua pihak, sehingga kegiatan ini diusulkan dan layak untuk ditindaklanjuti dalam rangka mengantisipasi kekerasan terhadap anak.

\section{METODE PELAKSANAAN}

Dalam meningkatkan kesadaran hukum terhadap penanganan anak yang berhadapan dengan hukum khususnya terhadap anggota Polisi di Kepolisian Resort (POLRES)Kabupaten TanjungJabung Baratdilakukan melalui pendekatan: pengembangan dan peningkatan SDM dengan beberapa tahapan.

\subsection{Aspek yang terkait}

Kegiatan akan dilakukan dengan mempertimbangkan beberapa aspek, yaitu :

1) Sumber Daya Manusia (khalayak sasaran /Mitra )

2) Nilai-nilai budaya dalam masyarakat

3) Tim pelaksana dan para nara sumber

4) Sarana dan prasarana

5) Peraturan Perundang-undangan

6) Pimpinan Perguruan Tinggi

Keenam aspek tersebut merupakan faktor yang saling terkait dan mendukung dalam pembentukan kesadaran hukum dalam masyarakat, khususnya terhadap hak asasi manusia.

Permasalahan yang sering terjadi dikarnakan perbedaan tingkatpengetahuan dan atau pemahaman terhadap aturan yang berlaku mengakibatkan suatu kesenjangan yang berpotensi memunculkanpermasalahan penanganan terhadap anak yang berhadapan dengan hukum. Untuk itu setiap masyarakat wajib memahami setiap aturan yang telah dibakukansecara formal baik dalam bentuk Undang-Undang, Perpu, Peraturan Pemerintah, Perda dan aturan lainnya sehingga terdapat satu persepsi dalam pola tindak dan pola pikir dalam berinteraksi.

\subsection{Metode yang digunakan}

Metode yang digunakan dalam kegiatan ini adalah "pelatihan peningkatan kesadaran hukum" dengan metode partisipatif pada kelompok sasaran mitra, artinya kelompok sasaran 
dituntut berperan aktif dalam mengikuti kegiatan dan tim penyuluh serta nara sumber berperan sebagai fasilitator. Pendekatan yang dilakukan baik secara kelompok maupun individu.

\subsection{Kelompok sasaran}

Kelompok sasaran yang strategis dalam kegiatan pelatihan ini adalah anggota Polisi di Kepolisian Resort (POLRES) Kabupaten Tanjung Jabung Barat yang seluruhnya berjumlah 30 (tiga puluh) orang.

\subsection{Materi kegiatan pelatihan}

1) Sosialisasi Undang-Undang Nomor 23 Tahun 2002 sebagaimana telah diubah melalui Undang-Undang Nomor 35 Tahun 2014 tentang Perlindungan Anak.

2) Penanganan terhadap anak yang berhadapan dengan hukum

3) Bentuk-bentuk dan batasan anak yang berhadapan dengan hukum

4) Nara Sumber

Nara sumber yang ditetapkan sebagai instruktur pelatihan penanganan terhadap anak yang berhadapan dengan hukum khususnya terhadap anggota Polisi di Kepolisian Resort (POLRES)Kabupaten TanjungJabung Baratdisajikan dalam tabel berikut:

\begin{tabular}{|c|c|c|c|}
\hline No & Materi Kegiatan & Nara Sumber & Asal Instansi \\
\hline 1 & \begin{tabular}{lrr} 
Sosialisasi & \multicolumn{2}{c}{ Undang-Undang } \\
Nomor 23 & Tahun 2002 \\
sebagaimana & telah diubah \\
melalui Undang-Undang Nomor & 35 Tahun 2014 tentang
\end{tabular} & $\begin{array}{l}\text { - Dr. Sri Rahayu, } \\
\text { S.H., M.H. }\end{array}$ & $\begin{array}{l}\text { Dosen Fak. Hukum } \\
\text { Unja }\end{array}$ \\
\hline 2 & $\begin{array}{l}\text { Penanganan terhadap anak yang } \\
\text { berhadapan dengan hukum }\end{array}$ & $\begin{array}{l}\text { - H. Hery Liyus, } \\
\text { S.H., M.H. }\end{array}$ & $\begin{array}{l}\text { Dosen Fak. Hukum } \\
\text { Unja }\end{array}$ \\
\hline 3 & $\begin{array}{l}\text { Bentuk-bentuk dan batasan anak } \\
\text { yag berhadapan dengan hukum. }\end{array}$ & $\begin{array}{l}\text { - Dheny Wahyudhi, } \\
\text { S.H., M.H. }\end{array}$ & $\begin{array}{l}\text { Dosen Fak. Hukum } \\
\text { Unja }\end{array}$ \\
\hline
\end{tabular}

\section{HASIL DAN PEMBAHASAN}

\subsection{Pelaksanaan}

\section{a. Lokasi}

Lokasi kegiatan penyuluhan tentang penanganan anak yang berhadapan dengan hukum kepada anggota polisi di Kepolisian Resort (POLRES) Kabupaten Tanjung Jabung Barat.

\section{b. Kelompok Sasaran}

Anggota Polisi di Kepolisian Resort (POLRES) Kabupaten Tanjung Jabung Barat yang seluruhnya berjumlah 30 (tiga puluh) orang.

\section{c. Materi kegiatan pelatihan}

1) Sosialisasi tentang Undang-Undang Nomor 23 Tahun 2002 tentang Perlindungan Anak sebagaimana telah diubah melalui Undang-Undang Nomor 35 Tahun 2014 tentang Perlindungan Anak. 
2) Penanganan terhadap anak yang berhadapan dengan hukum

3) Bentuk-bentuk dan batasan anak yang berhadapan dengan hukum

4) Kuis/evaluasi

Materi pelatihan yang diberikan kepada peserta pelatihan atau kelompok sasaran pada prinsipnya mencakup substansi Undang-undang Perlindungan Anak dan Penegakannya.

\section{d. Nara Sumber}

Nara sumber yang ditetapkan sebagai instruktur pelatihan peningkatan kesadaran hukum bagi masyarakat disajikan dalam tabel berikut:

\begin{tabular}{|c|c|c|c|}
\hline No & Materi Kegiatan & Nara Sumber & $\begin{array}{c}\text { Asal } \\
\text { Instansi }\end{array}$ \\
\hline 1 & $\begin{array}{l}\text { Sosialisasi Undang-Undang Nomor } 23 \\
\text { Tahun } 2002 \text { sebagaimana telah diubah } \\
\text { melalui Undang-Undang Nomor } 35 \text { Tahun } \\
2014 \text { tentang Perlindungan Anak } \\
\text { Penanganan terhadap anak yang berhadapan } \\
\text { dengan hukum }\end{array}$ & $\begin{array}{l}\text { - Dr. Sri Rahayu, } \\
\text { S.H., M.H. }\end{array}$ & $\begin{array}{l}\text { Dosen Fak. } \\
\text { Hukum Unja }\end{array}$ \\
\hline 2 & & $\begin{array}{l}\text { - H. Hery Liyus, } \\
\text { S.H., M.H. }\end{array}$ & $\begin{array}{l}\text { Dosen Fak. } \\
\text { Hukum Unja }\end{array}$ \\
\hline 3 & $\begin{array}{l}\text { Bentuk-bentuk dan batasan anak yag } \\
\text { berhadapan dengan hukum. }\end{array}$ & $\begin{array}{l}\text { - Dheny Wahyudhi, } \\
\text { S.H., M.H. }\end{array}$ & $\begin{array}{l}\text { Dosen Fak. } \\
\text { Hukum Unja }\end{array}$ \\
\hline
\end{tabular}

\section{PEMBAHASAN}

Kegiatan penyuluhan dilaksanakan berjalan dengan lancar dan tertib mendapat respon positif dari peserta penyuluhan. Banyak pertanyaan yang diajukan oleh peserta tidak hanya menyangkut tentang penanganan anak yang berhadapan dengan hukum akan tetapi juga permasalahan-permasalahan hukum lainnya yang berkembang dalam masyarakat.

Tingkat pengetahuan peserta sebelum diadakan kegiatan penyuluhan masih rendah belum begitu memahami tentang penanganan anak yang berhadapan dengan hukum dalam peradilan pidana anak dan upaya penanggulangan masalah-masalah hukum yang terjadi di masyarakat. Beberapa pertanyaan yang diajukan oleh masyarakat antara lain.

1. Bagaimana dengan kasus terhadap anak yang menggugurkan kandungannya (aborsi) akibat dari perkosaan?

2. Bagaimana penanganan anak yang berkonflik dengan hukum yang berusia 12 tahun?

3. Bagaimana penanganan anak yang melakukan pengulangan pengulangan tindak pidana?

4. Peranan Bapas dalam proses penanganan anak yang berhadapan dengan hukum?

5. Bagaimana sikap penyidik kalau sudah ada kesepakatan diversi pada tingkat penyidikan, tetapi pihak pengadilan tidak mau mengeluarkan surat penetapan diversi?

\section{MATERI KEGIATAN}

\section{Anak yang Berhadapan Dengan Hukum}

- Anak adalah seseorang yang berusia dibawah 18 (delapan belas) tahun termasuk anak yang masih berada didalam kandungan 
- System peradilan pidana anak adalah keseluruhan proses penyelesaian perkara anak berhadapan dengan hukum mulai tahap penyelidikan sampai tahap pembimbingan setelah menjalani pidana

- Anak yang berhadapan dengan hukum adalah anak yang menjadi korban tindak pidana dan anak yang menjadi saksi tindak pidana

- Anak yang berkonflik dengan hukum yang sselanjutnya disebut anak yang telah berumur 12 (dua belas) tahun tapi belum berusia 18 (delapan belas) tahun yang di duga melakukan tindak pidana

- Anak yang menjadi saksi tindak pidana adalah anak yang melihat, mendengar dan/atau mengalami sendiri suatu tindak pidana

- Anak yang Menjadi Korban Tindak Pidana yang selanjutnya disebut Anak Korban adalah anak yang belum berumur 18 (delapan belas) tahun yang mengalami penderitaan fisik, mental, dan/atau kerugian ekonomi yang disebabkan oleh tindak pidana

- Anak yang Menjadi Saksi Tindak Pidana yang selanjutnya disebut Anak Saksi adalah anak yang belum berumur 18 (delapan belas) tahun yang dapat memberikan keterangan guna kepentingan penyidikan, penuntutan, dan pemeriksaan di sidang pengadilan tentang suatu perkara pidana yang didengar, dilihat, dan/atau dialaminya sendiri.

- Keadilan Restoratif adalah penyelesaian perkara tindak pidana dengan melibatkan pelaku, korban, keluarga pelaku/korban, dan pihak lain yang terkait untuk bersama-sama mencari penyelesaian yang adil dengan menekankan pemulihan kembali pada keadaan semula, dan bukan pembalasan.

- Diversi adalah pengalihan penyelesaian perkara Anak dari proses peradilan pidana ke proses di luar peradilan pidana.

- Pembimbing Kemasyarakatan adalah pejabat fungsional penegak hukum yang melaksanakan penelitian kemasyarakatan, pembimbingan, pengawasan, dan pendampingan terhadap Anak di dalam dan di luar proses peradilan pidana.

- Lembaga Pembinaan Khusus Anak yang selanjutnya disingkat LPKA adalah lembaga atau tempat Anak menjalani masa pidananya

- Lembaga Penempatan Anak Sementara yang selanjutnya disingkat LPAS adalah tempat sementara bagi Anak selama proses peradilan berlangsung.

- Balai Pemasyarakatan yang selanjutnya disebut Bapas adalah unit pelaksana teknis pemasyarakatan yang melaksanakan tugas dan fungsi penelitian kemasyarakatan, pembimbingan, pengawasan, dan pendampingan

\section{Asas peradilan pidana anak :}

- Perlindungan

- Keadilan

- Nondiskriminasi

- Kepentingan terbaik bagi anak

- Penghargaan terhadap pendapat anak

- Kelangsungan hidup dan tumbuh kembang anak

- Pembinaan dan pembimbingan anak

- Proposional

- Perampasan kemerdekaan dan pemidanaan sebagai upaya terakhir Penghindaran pembalasan

- Tidak dipublikasikan identitasnya

- Memperoleh pendampingan orang tua/wali

- Memperoleh advokasi 
- Memperoleh pelayanan kesehatan, pendidikan

Anak yang berkonflik dengan hukum:

- Anak yang telah berumur 12 tahun tetapi belum berumur 18 tahun yang duduga melakukan tindak pidana.

- Anak korban tindak pidana belum berumur 18 tahun yang mengalami penderitaan fisik, mental kerugian ekonomi akibat tindak pidana

- Anak yang menjadi saksi belum berumur 18 tahun yang dapat memberikan keterangan guna kepentingan pemeriksaan perkara pidana

\section{Proses Peradilan Anak}

- Penyidikan

- Penuntutan

- Pemeriksaan pengadilan

\section{Dalam hal anak belum berumur 12 tahun melakukan tindak pidana:}

- Penyidik mengambil keputusan:

- Menyerahkan kepada orang tua

- Menyertakan dalam program pendidikan, pembinaan, dan pembimbingan di instansi LPKS

\section{Penahanan terhadap anak:}

- Anak telah berumur 14 tahun atau lebih

- Diduga melakukan tindak pidana dengan ancaman pidana penjara 7 tahun atau lebih

\section{Lama penahanan terhadap anak yg diproses dalam peradilan pidana:}

- $\quad$ Tingkat penyidikan 7 hari -8 hari

- Tingkat penuntutan 5 hari - 5 hari

- Persidanagan pengadilan 10 hari - 15 hari

\section{Jenis pidana}

- Pidana pokok bagi anak:
a. Pidana peringatan
b. Pidana dengan syarat (pembinaan di luar lembaga, pelayanan masyarakat dan pengawasan)
c. Pelatihan kerja
d. Pembinaan dalam lembaga
e. Penjara

- Pidana Tambahan terdiri:
a. Perampasan keuntungan yang diperoleh dari tindak pidana
b. Pemenuhan kewajiban adat
c. Anak yang belum berumur 14 tahun hanya dapat dikenai tindakan

\section{Tindakan bagi anak:}

- Pengembalian kepada orang tua

- Penyerahan kepada seseorang

- Perawatan di rumah sakit jiwa 
- Perawatan di LPKS

- Kewajiban mengikuti pendidikan formal atau pelatihan yang diadakan oleh pemerintah atau swasta

- Pencabutan SIM

- Pemenuhan kewajiban adat

\section{Diversi:}

Pengertian:

- Diversi adalah pengalihan penyelesaian perkara anak dari proses peradilan pidana ke proses di luar peradilan pidana

\section{Tujuan :}

- Mencapai perdamaian korban dan anak

- Menyelesaikan perkara anak di luar prosesperadilan

- Menghindarkan anak dari perampasan kemerdekaan

- Mendorong masyarakat untuk berpartisipasi

- Menanamkan rasa tanggung jawab kepada anak

- Diversi dilaksanakan dalam hal:

- Tindak pidana yang dilakukan diancam dengan pidana penjara di bawah 7 tahun

- Bukan merupakan pengulangan tindak pidana

\section{Proses Diversi:}

- Proses diversi dilakukan melalui musyawarah dengan melibatkan anak dan orang tua/walinya, korban dan /atau orang tua/walinya, Pembimbing Kemasyarakatan, dan Pekerja Sosial Profesional berdasarkan pendekatan keadilan restoratif

\section{Proses diversi wajib mempertimbangkan:}

- Kepentingan korban

- Kesejahteraan dan tanggung jawab anak

- Penghindaran stigma negatif

- Penghindaran pembalasan

- Keharmonisan masyarakat

- Kepatutan, kesusilaan dan ketertiban umum

Penyidik, Penuntut Umum, dan Hakim dalam melakukan diversi harus memperhatikan:

- Kategori tindak pidana

- Umur anak

- Hasil penelitian kemasyarakatan dari BAPAS

- Dukungan lingkungan keluarga dan masyarakat

\section{Hasil kesepakatan diversi :}

- Perdamaian dengan atau tanpa ganti kerugian

- Penyerahan kembali kepada orang tua/wali

- Keikutsertaan dalam pendidikan atau pelatihan di lembaga pendidikan atau LPKS paling lama 3 bulan

- Pelayanan masyarakat 


\section{Anak saksi dan anak korban berhak atas semua perlindungan dan hak yang diatur dalam undang-undang}

- Anak korban dan anak saksi berhak atas;

1. Upaya rehabilitasi medis, rehabilitasi sosial baik di dalam lembaga maupun di luar lembaga

2. Jaminan keselamatan baik fisik, mental, maupun sosialKemudahan

\section{Peran serta masyarakat:}

- Masyarakat dapat berperan serta dalam perlindungan anak mulai dari pencegahan sampai dengan reintegrasi sosial anak dengan cara:

- Menyampaikan laporan terjadinya pelanggaran hak anak

- Mengajukan usulan mengenai perumusan dan kebijakan yang berkaitan dengan anak

- Melakukan pendidikan dan penelitian mengenaianak

- Berpartisipasi dalam penyelesaian perkara anak melalui diversi dan keadilan restoratif

- Berkontribusi dalam rehabilitasi dan reintegrasi sosial anak, anak korban dan/atau anak saksi melalui organisasi kemasyarakatan

- Melakukan pemantauan terhadap kinerja aparat penegak hukum dalam penanganan perkara anak

- Melakukan sosialisasi mengenai hak anak serta peraturan perundang-undangan yang berkaitan dengan anak.

\section{Prinsip Dasar Konvensi Hak Anak}

- Non diskriminasi

- Kepentingan yang terbaik bagi anak

- Hidup, kelangsungan hidup dan perkembangan anak

- Penghargaan terhadap partisipasi anak.

\section{Pasal 3}

Dalam semua tindakan yang menyangkut anak, maka kepentingan terbaik bagi anak harus dijadikan pertimbangan utama. Negara peserta berupaya untuk menjamin adanya perlindungan dan pemeliharaan sedemikian rupa yang diperlukan untuk kesejahteraan anak. Baik lembaga maupun instansi-instansi beserta fasilitas-fasilitasnya, bertanggung jawab atas pemeliharaan dan perlindungan anak. Terutama dalam bidang keselamatan, kesehatan, dan adanya pengawasan yang baik.

\section{Pasal 5}

Negara peserta harus menghormati tanggung jawab, hak dan kewajiban orang tua atau komunitas sebagaimana ditentukan oleh adat setempat. Pengarahan dan bimbingan dalam pelaksanaan hak-hak yang diakui dalam KHA dengan cara yang sesuai dengan perkembangan kemampuan seorang anak.

\section{Pasal 12}

Negara peserta harus menjamin bahwa anak-anak yang mampu membentuk pandangannya sendiri, mempunyai hak menyatakan pendapatnya secara bebas. Pendapat anak-anak dipertimbangkan sesuai dengan usia dan kematangan mereka. Untuk tujuan ini, anak diberi kesempatan untuk didengar dalam setiap proses peradilan dan administratif yang mempengaruhi dirinya, baik langsung maupun melalui perwakilan dengan cara yang sesuai 
denga hukum acara nasional.

\section{Pasal 37a}

Tidak seorang anak pun akan mengalami siksaan atau kekejaman-kekejaman lainnya, perlakuan atau hukuman yang tidak manusiawi, atau yang menurunkan martabat. Hukuman mati maupun hukuman seumur hidup tanpa kemungkinan dibebaskan, tidak akan dikenakan untuk kejahatankejahatan yang dilakukan seorang yang berusia di bawah 18 tahun.

\section{Pasal 37b}

Tidak seorang anakpun akan kehilangan kebebasannya secara tidak sah dan sewenang-wenang. Penangkapan, penahanan, atau penghukuman anak akan disesuaikan dengan undang-undang dan akan digunakan hanya sebagai langkah terakhir dan untuk nasa yang paling singkat dan layak.

\section{Pasal 37c}

Setiap anak yang dirampas kebebasannya akan diperlakukan secara manusiawi dan dengan menghormati martabat seorang manusia dan cara yang memberi perhatian kepada kebutuhankebutuhan orang seusianya. Secara khusus, setiap anak yang dirampas kebebasannya akan dipisahkan dari orang dewasa kecuali bila tidak melakukannya dianggap sebagai kepentingan yang terbaik dari anak yang bersangkutan dan anak mempunyai hak untuk terus mengadakan hubungan dengan keluarganya melalui surat menyurat atau kunjungan, kecuali dalam keadaan luar biasa.

\section{Pasal 37d}

Setiap anak yang dirampas kebebasannya akan diperlakukan secara manusiawi, dan dengan cara yang memberi perhatian kepada kebutuhan-kebutuhan orang seusianya. Setiap anak yang dirampas kebebasannya akan mempunyai hak untuk segera mendapat bantuan hukum dan bantuan-bantuan lainnya yang layak.

\section{Pasal 39}

Semua langkah yang tepat untuk meningkatkan pemulihan fisik maupun biologis dan reintegrasi dalam masyarakat, seorang anak yang menjadi korban dari setiap bentuk penelantaran, eksploitasi, atau setiap hukuman yang kejam. Pemulihan fisik maupun psikologis dan reintegrasi dilakukan dalam suatu lingkungan tanpa diskriminasi, demi kepentingan.

\section{Pasal 40}

- Setiap anak yang diduga, dituduh atau diakui sebagai telah melanggar undang-undang hukum pidana akan diperlakukan dengan cara konsisten.

- Tak seorang anak pun akan diduga, dituduh, atau diakui sebagai telah melanggar undangundang. Setiap anak yang diduga atau dituduh telah melanggar undang-undang hukum pidana berhak atas jaminan legal : dianggap tidak bersalah sebelum dibuktikan bersalah, hak atas pengadilan yang cepat, memperoleh bantuan hukum, hak atas seorang penerjemah

\section{Dasar Hukum}

- Konvensi dan resolusi PBB tentang Hak-hak Anak.

- Undang-Undang Nomor 8 Tahun 1981 tentang Hukum AcaraPidana (KUHAP). 
- Undang-Undang Nomor 5 Tahun 1998 tentang Ratifikasi CAT(Convention Against Torture).

- Undang-Undang Nomor 39 Tahun 1999 tentang Hak AsasiManusia.

- Undang-Undang Nomor 2 Tahun 2002 tentang Kepolisian NegaraRepublik Indonesia.

- Undang-Undang Nomor 35 Th 2014, perubahan thd UUNomor 23 Tahun 2002 tentang Perlindungan Anak,

- Undang-Undang Nomor 23 Tahun 2004 tentangPenghapusan Kekerasan Dalam Rumah Tangga.

- Undang-Undang Nomor 11 Tahun 2012 tentang Sistim Peradilan Pidana Anak

- Undang-Undang Nomor 13 Tahun 2006 tentangPerlindungan Saksi dan Korban.

- Keputusan Presiden RI. Nomor 36 Tahun 1990 tentangRatifikasi Konvensi Hak Anak.

- Keputusan Bersama Ketua Mahkamah Agung RI, Jaksa Agung RI, Kepala Kepolisian Negara RI, Menteri Hukum dan HAM RI, Menteri Sosial RI dan Menteri PP dan PA RI Nomor: 166A/KMA/SKB/XII/2009, Nomor: 148 A/A/JA/12/2009, Nomor: B/45/XII/2009, Nomor: M.HH-08 HM.03.02 Tahun 2009, Nomor: 10/PRS-2/KPTS/2009 dan Nomor: 02/Men.PP dan PA/XII/2009 tentang Penanganan Anak Yang Berhadapan dengan Hukum $(\mathrm{ABH})$;

- Peraturan Kapolri Nomor 10 Tahun 2007 tentang Organisasi dan Tata Kerja Unit Pelayanan Perempuan dan Anak (Unit PPA) di Lingkungan Kepolisian Negara Republik Indonesia.

- Peraturan Kapolri Nomor 3 Tahun 2008 tentang Pembentukan Ruang Pelayanan Khusus dan Tata Cara Pemeriksaan Saksi dan/ atau Korban Tindak Pidana.

- Peraturan Kapolri Nomor 8 tahun 2009 tentang Implementasi HAM oleh Polri.

\section{PENUTUP}

1. Peningkatan pengetahuan peserta tentang penanganan anak yang berhadapan dengan hukum.

2. Peserta penyuluhan mampu menyampaikan beberapa permasalahan yang berkembang dalam masyarakat secara berpariatif.

3. Peserta penyuluhan sangat antusias, tertib dan aktif bertanya berkaitan dengan tugas penyidikan.

\section{DAFTAR PUSTAKA}

\section{Buku}

Esmi Warassih Puji Rahayu. 2005. Pranata Hukum Sebuah Telaah Sosiologis,Semarang: Suryandaru Utama.

Muladi dan Barda Nawawi Arief. 1984. Teori-teori dan Kebijakan Pidana,Alumni: Bandung.

Muladi.1995. Kapita Selekta Sistem Peradilan Pidana, Semarang: Badan Penerbit Universitas Diponegoro.

Rika Saraswati. 2009. Hukum Perlindungan Anak di Indonesia.Citra Aditya

Bakti. Bandung.

Soerjono Soekanto, 1984, Metode Penelitian Hukum, UI Press, Jakarta 
2005. Faktor-faktor Yang Mempengaruhi Penegakan Hukum,Jakarta: Raja Grafindo Persada.

Waluyadi. 2009. Hukum Perlindungan Anak. Mandar Maju. Bandung.

\section{Undang-Undang}

Undang-Undang Nomor 23 Tahun 2002 sebagaimana telah diubah melalui Undang-Undang

Nomor 35 Tahun 2014 tentang Perlindungan Anak

Undang-Undang Nomor 11 Tahun 2012 Tentang Sistem Peradilan Pidana Anak

Undang-Undang Nomor 4 Tahun 1979 Tentang Kesejahteraan Anak

Kepres No. 36 Tahun 1990 Tentang Pengesahan Convention of The Rights/Konvensi Tentang Hak-hak Anak 